\title{
ICT in Primary Education. Review of its importance and a proposal
}

DOI: $10.46932 / \mathrm{sfjdv2n1-012}$

Received in: November 1st, 2020

Accepted in: December 30th, 2020

\author{
Mario Gómez González \\ Máster Profesorado. CAFD. Primaria. \\ Universidad de Murcia \\ Calle Rosalía de Castro, 44, 30107 Murcia \\ Jose María Rabal Alonso \\ Profesor ISEN Centro Universitario \\ Instituição: Universidad de Murcia \\ Calle Campus Universitario, 12, 30100 Murcia \\ E-mail: josemaria.rabal@um.es
}

\begin{abstract}
This innovative study arises in response to the current educational reality, observed during an internship in a specific educational center. It is a methodological proposal to be applied in teaching, specifically, primary school students, to improve the academic performance of these students.

The educational reality that future teachers face is, without a doubt, a difficult challenge that, with motivation and work, we must achieve to meet the objectives set each academic year and there is where the use of ICT takes its part.
\end{abstract}

Key words: ICT, didactic unit, emotions, learning, Primary Education.

\section{JUSTIFICATION}

After years of experience, we have found that some of the students in this stage are easily distracted, bored and do not pay the necessary attention to the lesson taught by the teacher. This brings with it a series of consequences, for example, in the time dedicated to the explanation of a certain concept. When a student does not understand something because he is not attentive enough to the teacher, is thinking about other things, or talking to a classmate, he has to ask the teacher to repeat the presentation since he has not understood what was just said; This results in the employment of twice the expected time.

However, in the practice of technology-related activities, students received them as interesting and were happy, cheerful and motivated, thus causing an increase in their involvement.

Human beings act motivated by something that motivates us. Thus, if we like something we quickly learn it, and if it seems boring, it is more complicated for us.

To talk about motivation in education, it is important to bear in mind that, in the teaching-learning process, the protagonists are two: the student and the teacher. With this premise in mind, the course should 
be planned and tried to be as productive as possible.

Today, these students live in a world where ICTs are important, where technologies are the order of the day, and children can have more independence. However, we are faced in many cases, with situations where students need motivation in order to achieve the maximum performance and participation of the students.

For this reason, when one of the protagonists of the teaching-learning process is not fully involved, it must be the other protagonist who acts correctly and provides the necessary incentive for proper learning. Taking this into account, the teacher should choose the most appropriate option to encourage the process.

The characteristics that the alternatives to be applied must possess can be, for example, creativity, originality, innovative activities, influential, and, mainly, motivating. This is because motivation is what moves people to achieve things.

Regarding the difference between one type of exercise and others, we see how the students are more cheerful and motivated, as a rule, in exercises related to technologies than the rest of the more traditional exercises. This is because it is a more fun and enjoyable activity, where a friendly climate is established.

This leads to think that, when faced with something they like, children interact more, are more applied in practice and teaching, and pay more attention.

From the lived experience, it is concluded that carrying out activities related to ICT causes them greater happiness and well-being than sitting in a class listening only to the teacher with conventional means.

Therefore, the purpose of this TFG is to demonstrate a positive influence of the practice of activities with technological tools, in terms of the joy and motivation they produce, in elementary school students, and to take advantage of this influence to increase their academic performance.

The activities on which this study will focus are activities related to ICT. The reason for my choice was that it is a topic that is currently being widely extended by the Spanish population. In the society we live in today, technology is used, and it is interesting that children from a very young age begin to practice with them to function effectively in the future. In addition, it is a way of acquiring knowledge in a playful way, improving student performance, and fulfilling the learning objective.

From what has been said in these lines, we could ask ourselves: does the practice of activities related to technology cause psychological benefits in elementary school students? And what is more important in the field that concerns us, do these psychological characteristics influence the academic performance of our students? 


\section{THEORETICAL FRAMEWORK}

\subsection{ICT IN EDUCATION}

Information and Communication Technologies (ICT) have been researched for years. They are instruments of great help for teaching. Over the years, the impact of ICTs has become notorious, publishing any type of research. In this way, it was given the deserved importance, considering online learning or "e-learning" as a new dimension (Borja \& Gutiérrez, 2016).

The exposure of the new generations to the use of technology is not a question of generational predisposition, but rather an unavoidable exposure that forces these generations to use technology early, continuously and practically unavoidable (Pérez, 2018) .

In fact, a report published by the INE, Minors and Mobile Connectivity in Spain states that the introduction of mobile phones in the child population (10-15 years) has increased three points in recent years, in such a way that 67\% in 2015, it went to almost 70\% in 2017 (Pérez, 2018).

ICTs have had a great impact on the knowledge society, causing great changes in form and content, with intense effect, so that it has penetrated into society in general. One of the areas where more modifications have been seen due to these technologies has been education and school (Hernández, 2017).

In the beginning, ICT was focused and centered on technology-based learning. Currently, the focus is on the student and the methodology. The objective would be to improve the quality of the interaction, making use of the computer to facilitate collaborative learning, as well as focusing on cooperative work between the teacher and the student. In this way, it is intended to achieve an active participation and interaction between both (Salinas, 2004).

The use of ICT implies breaking with the traditional means used in education, such as blackboards, pencils, etc., and advancing in teaching based on the demand to update teaching methods

depending on current requirements, so as not to be anchored in the past, in an outdated education that does not motivate the student (Hernández, 2017).

As has been commented, ICTs are instruments that greatly favor teaching. In this way, the main functions of ICT in educational centers are, among others:

- Digital literacy in students.

- Access to information, communication and data management and processing.

- Facilitate teaching and learning processes by learning to use ICT (Cladellas \& Castelló, 2010).

The use of information and communication technologies are having a great impact on education. So much so that qualitative changes have even been carried out, especially in the illustration of the agenda 
through audiovisual material. Another advantage of using technologies is that provided by computer simulations (Cladellas \& Castelló, 2010).

It is possible to stage situations as real as possible, having the option of modifying the parameters as we are interested. This resource can make us arrive at 3D formats so that students can easily acquire the knowledge that is required (Cladellas \& Castelló, 2010).

Other advantages of using ICT (Cladellas \& Castelló, 2010):

- Take advantage of resources. In this way it will not be necessary to go to certain places to obtain knowledge, with technology you can reach places without having to be physically there. If we want to know about a specific place, with the simulation of a video we can consolidate the learning.

- Relationship between people. With the use of ICT, you can have a more direct contact between parents, teachers and students almost instantly.

- Motivation. The students associate technology with playful activity. In this way we activate positive emotional states in children, thus managing to maintain attention to the activity for longer than before other more conventional means.

- Autonomous Learning. Through computer programs, "feedback" can be provided to students, so that they can

report errors immediately. Improving skills and establishing a friendly climate unlike other older media.

- Easy access to any information. On the internet there is a significant volume of information, both textual and audiovisual. This information can be used to facilitate learning. It is necessary to know how to differentiate between the quality of information and the quantity of it.

It is interesting to know the advantages that ICT can offer us. However, there are also situations where using technologies can have disadvantages:

- The use of ICT entails a cultural and social transformation that affects such important points as human relationships, the world of work, study and entertainment (Suasnabas, Ávila, Díaz \& Rodríguez, 2017).

- Distractions It is possible that ICTs have a more playful approach than an educational one. In this way, the proposed objective will not be pursued (Cladellas \& Castelló, 2010).

- Unreliable information. As has been commented on the advantages of ICT, we have a lot of information on the internet, but this may not be reliable, obsolete or be wrong (Cladellas \& Castelló, 2010).

- Incomplete and superficial learning. By getting a lot of information in a short time, simplistic and 
shallow learning can be carried out (Cladellas \& Castelló, 2010).

There is an imbalance between what educational policies ask teachers in terms of ICT, and the knowledge and technological resources that teachers have to be able to reach the objectives set. Most of the teachers do not have knowledge about technology that can be used to carry out the educational process (Fuentes, Carrera \& Fernández, 2017).

It is vitally important to indicate that, without adequate training of teachers in technology, adapted to the teaching sector, investment in it will be of little use (Suasnabas et al., 2017).

The school must also be integrated into the new changes that today presents us. It is therefore important to carry out digital literacy, to be able to function in the best way today. This objective has to be carried out following certain parameters, based on a reason and not as if it were a fashion (Cladellas \& Castelló, 2010).

ICTs can be considered as valuable resources in learning, since they are capable of achieving the training of students with certain personal and professional skills appropriate for the development of a country (Hernández, 2017).

In this way, the teaching-learning process in class, through the use of ICT, requires a series of competencies that the teacher must achieve, taking advantage of the technological tools available today. Thus, teacher training for the use of these should be considered as one of the main objectives to take into account to face the new educational challenges (Hernández, 2017).

\subsection{SOCIAL NETWORKS IN EDUCATION.}

It is obvious that the use of social networks by young people and adults is increasing exponentially every day. It could be said that we live in the "era of hyperconnectivity" (Cabero, Barroso, Llorente \& Yanes, 2016).

Social networks are growing at a tremendous rate, and are gaining ground in various areas, such as cultural, social, educational, and business (Pérez, Ortiz \& Flores, 2015).

They are used to find and maintain conversation with lost friends, debate about a wide variety of topics, organize meetings with friends, former classmates, as well as to give visibility to congresses and conferences (De Haro, 2010).

Currently, social networks are one of the forms of communication that both children and young people use the most. Care should be taken with the use of these, since their excessive use can cause psychological damage and addiction (Muñoz, Fragueiro \& Ayuso, 2013).

However, if we use them properly, social networks can be an important tool in education as a way 
of teaching and learning, in which the student would be immersed in a great cooperative work (Muñoz et al., 2013).

In this way, the educational world cannot remain oblivious to this social phenomenon, which is causing a great change in the way of communication between people. The education system basically works with information, so it would not make sense to use publication or transmission systems used almost a century ago, and not take advantage of what society has established in its daily life. It is necessary to update to what we have today (De Haro, 2010).

Within educational institutions, there has been a growing interest in knowing and incorporating social networks for academic uses, and thus achieving an impact in the teaching environment and in the training processes of students (Pérez et al., 2015).

In this way, the use of social networks has expanded in the educational field as an alternative to reinforce face-to-face education, or as another instrument in virtual education (Pérez et al., 2015).

Social media is of great importance for communication in many ways, including educational. Not only do they help new forms of learning such as collaborative, but they offer a world of information and possibilities. With which, the world of social networks has an important weight, so it would be interesting for us to know how to use them (Buxarrais, 2016).

In this way, thanks to the development and incorporation of social software tools, students can interact with each other in the best possible way. Specifically, social networks can change a large number of cultural forms (Cabero et al., 2016).

The flexibility of the networks makes it possible for their applications to be as high as teachers can use them. There are, therefore, different ways of using them in education, some of them are, for example (De Haro, 2010):

\section{- Subject networks}

- Networks of educational centers and groups to create internal communities.

- Groups to consult doubts and teaching activity of subjects.

- Group with a bulletin board for a subject.

- Groups of students.

- Tutoring of works.

Regarding collaborative work through social networks, discussed below, one of the most relevant characteristics is that these media help students to be connected and allow them to share the content they generate themselves. Thus, even people from different parts of the world can work together in the same collaborative writing activity on pages, to create a social text (Cabero et al., 2016). Some of the 
characteristics of social networks are (Pérez et al.,

2015):

a. Individual connectivity: users create an individual profile for their registration, each person searches for their affiliation freely.

b. Independence and Interactivity: they are created based on common motivations and interests; this entails independent integration. On the other hand, Interactivity takes place from how the subjects receive and transmit information to achieve communication.

c. Freedom: it is about the independence that each subject has with social networks, in the dissemination of information or creation of content to build knowledge.

Related to the use of social networks for educational purposes, Martínez et al. (2012) carried out research with adolescents to study social interactions on networks, and observed that young people often have difficulties using them for this purpose. It is for this reason that they declare an essential aspect to train both young people and teachers, and thus strengthen their use with these ideas, in addition to studying the mode of communication and interaction that occurs between them to increase their use (Pérez et al. ., 2015).

Childwise's Connected Kids Report conducted a cross-sectional study from 1995 to 2017, providing a detailed picture of children's media consumption. This report

shows that adolescents spend approximately 7 and a half hours looking at screens, communicating with other people and interacting on social networks (Pérez, 2018).

In this way, it can be concluded that the degree of use of both smartphones and social networks among primary school students implies an important field of research for the study and implementation of new educational models, which should be carried out carried out in a formal way, from the schools, and thus take advantage of the evident potential for access, use and scope that they present (Pérez, 2018).

\subsection{COLLABORATIVE LEARNING THROUGH ICTS.}

Throughout history, learning together is something quite common, but at the end of the 20th century collaborative learning appeared, becoming an interesting topic of study.

Here are three responses to the importance of collaborative learning:

- A new technological and digital era that did not exist before, connecting millions of people regardless of where they are. In summary, ICTs are a concept in which the collaborative nature of learning can develop.

- Three characteristics of important relevance for collaboration based on technological learning: 
interactivity, ubiquity, and synchronism.

- The sociocultural approach valued the social as part of the individualized cognitive process (Zañartu, 2011).

Some of the main benefits for students of collaborative learning are:

- Academics, increases the good results in class since it gives importance to the participation and construction of knowledge of the students themselves.

- Social, get them to understand each other around a positive atmosphere by developing learning.

- Psychological, increases the self-esteem of students and the positive relationship between students and teachers (Guitert \& Perez-Mateo, 2013).

Collaborative learning makes each person responsible for their learning. Both individual and group capacities are enhanced through discussion between students. Individualized tutoring must be taken into account to carry out this ICT-supported learning. In this way, the demands of the students will be facilitated in the process. We must make it clear what collaborative learning consists of (Jorrín, Vega \& Gómez, 2004). The collaborative learning method is based on the principle of "learning by doing", characterized by addressing relevant and difficult aspects of the curriculum, in a meaningful, authentic, autonomous and constructive way, in such a way that the completion is to achieve a product or achievement, whether of a curricular or more general nature, such as personal development and training.

These achievements will be beneficial for both students and teachers (García-Valcarcel \& Basilotta, 2015).

In this sense, it is important to mention that ICTs, already mentioned previously, have contributed significantly to the task of providing the necessary instruments to improve collaborative work. Furthermore, both networks and learning communities can exist thanks to the socialization and personal exchange that takes place thanks to these technological supports (García-Valcárcel \& Basilotta, 2015).

Most of the students believe that collaboration consists of completing a part of the work, without being aware of what the rest of the classmates are doing. However, stereotypes were broken explaining the importance of joint work, discussion and role-sharing as fundamental strategies. Generalizing, the collaborative learning processes carried out with technological tools, improves the quality and enriches the old strategies of university teaching (Jorrín et al., 2004). 


\section{OBJECTIVES}

\subsection{GENERAL PURPOSE}

Increase the motivation of primary school students through activities where ICT are used, to achieve an improvement in academic performance.

\subsection{SPECIFIC OBJECTIVES}

1) Increase the psychological aspects of primary school students, to achieve the learning objective in a playful way.

2) Make students aware of the importance of knowing how to handle new technologies.

3) Encourage cooperation between students through collaborative and cooperative work, as a team and individually.

4) Facilitate digital and audiovisual literacy to know and use ICT appropriately.

5) Improve optimism to achieve greater involvement in activities.

\section{METHODOLOGY}

\section{Contextualization}

Through the methodology used, it is intended to solve the objectives proposed above. The methodological proposal of this project is based on the implementation of a Didactic Unit, composed of 8 sessions, of 20 hours in total.

This work will focus on students belonging to 5th grade of Primary with their 3 corresponding groups (A, B and C) each, from four different institutes in the Region of Murcia. In total, it is expected to work with the participation of approximately 400 students.

In addition, the grades of students from previous years will be taken as a reference, belonging to the same academic courses studied in

this year, but with a characteristic that differentiates them: the latter will not have made the excursions to the natural environment of which the Didactic Unit to be treated consists.

This analysis will take place during an academic year (2019-2020), in order to observe an evolution over time. The difference in academic performance will be examined in those students who, due to the practice of activities related to ICT, for example, are more optimistic and, as a consequence, obtain better results in studies. 


\subsection{CONTENTS}

\section{Attitudinal contents:}

- $\quad$ Care of technological tools (computers, digital board, video camera, recorder, etc.).

- Interest in the use of information and communication technologies (ICT).

- $\quad$ Respect for the work of the partner.

\section{Procedural contents:}

- $\quad$ Treatment of ICT in the educational field and management of different applications and web pages to carry out activities.

- Knowledge through playful learning of the importance of technological tools in education.

- Exploration of various technological sources of information.

- $\quad$ Individual and group work.

\section{Conceptual contents:}

- $\quad$ Mathematics.

- $\quad$ Spanish Language and Literature.

- $\quad$ Social and Nature Sciences.

- Religion.

- Musical education.

\subsection{TIMING AND ACTIVITIES}

\section{Schedule:}

Session 1: Wrong spelling (2 hours).

Session 2: Unbeatable holidays (3 hours).

Session 3: Digital mathematics (2 hours).

Session 4: Music styles (2 hours).

Session 5: Digital baptism (3 hours).

Session 6: In search of Europe (2 hours).

Session 7: History in contest (2 hours).

Session 8: Interactive social network (2 hours). 
Next, the proposed sessions will be presented. In the first place, the necessary sessions will be held with the students in class, where an explanation of the main aspects of the applications that will be used in the activities will be carried out. After this, and once its operation is understood, the activity sessions will begin.

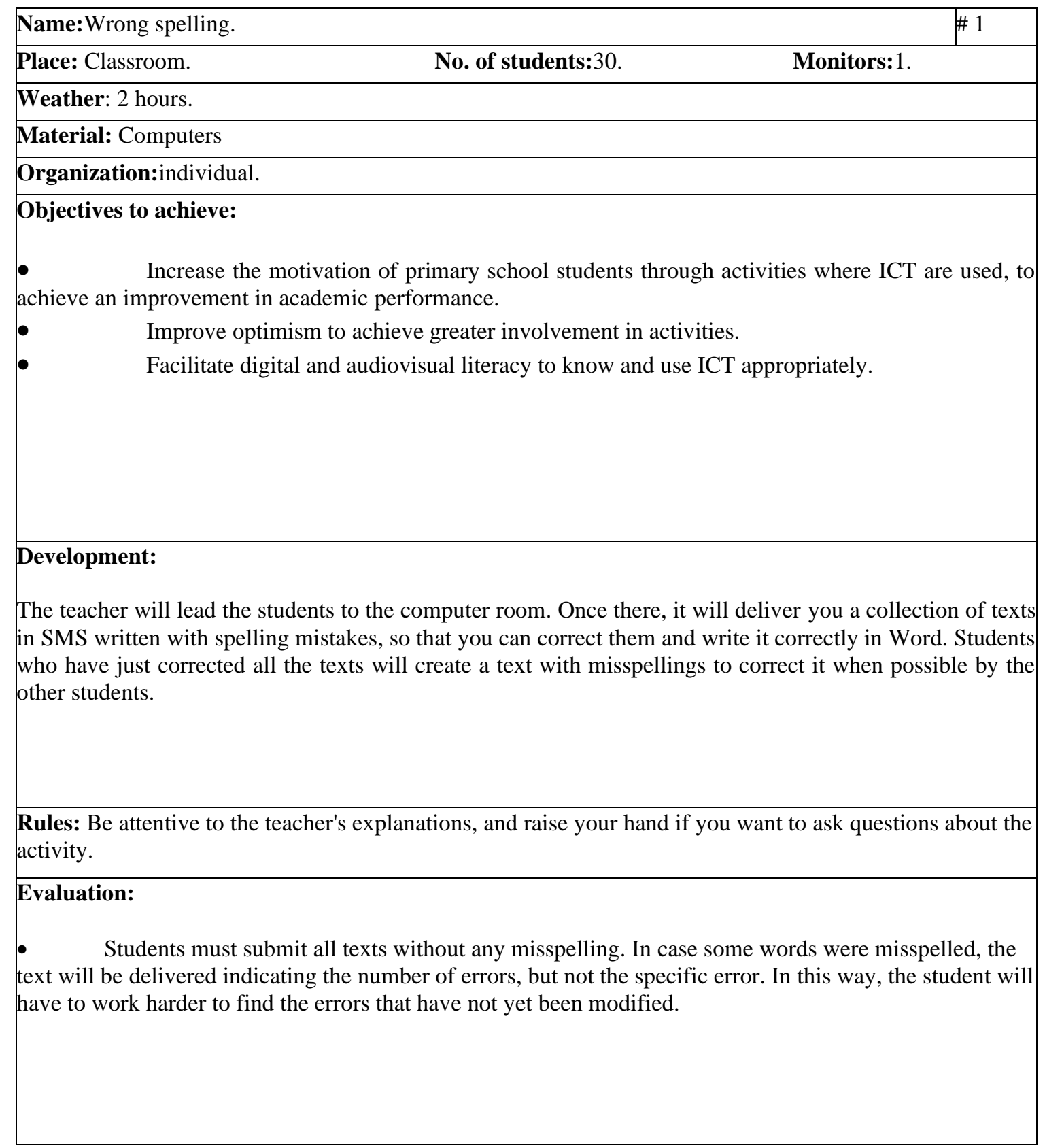




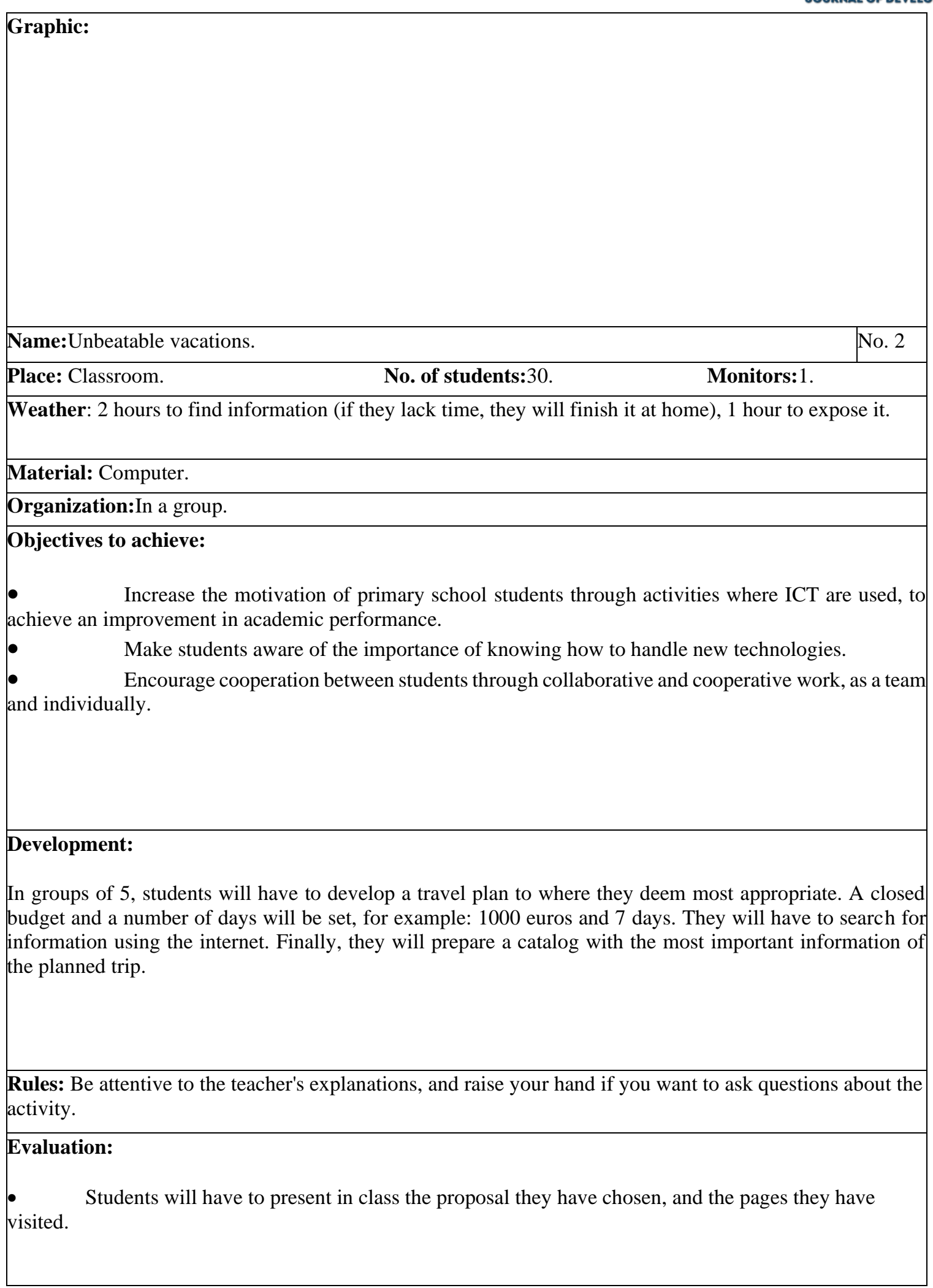




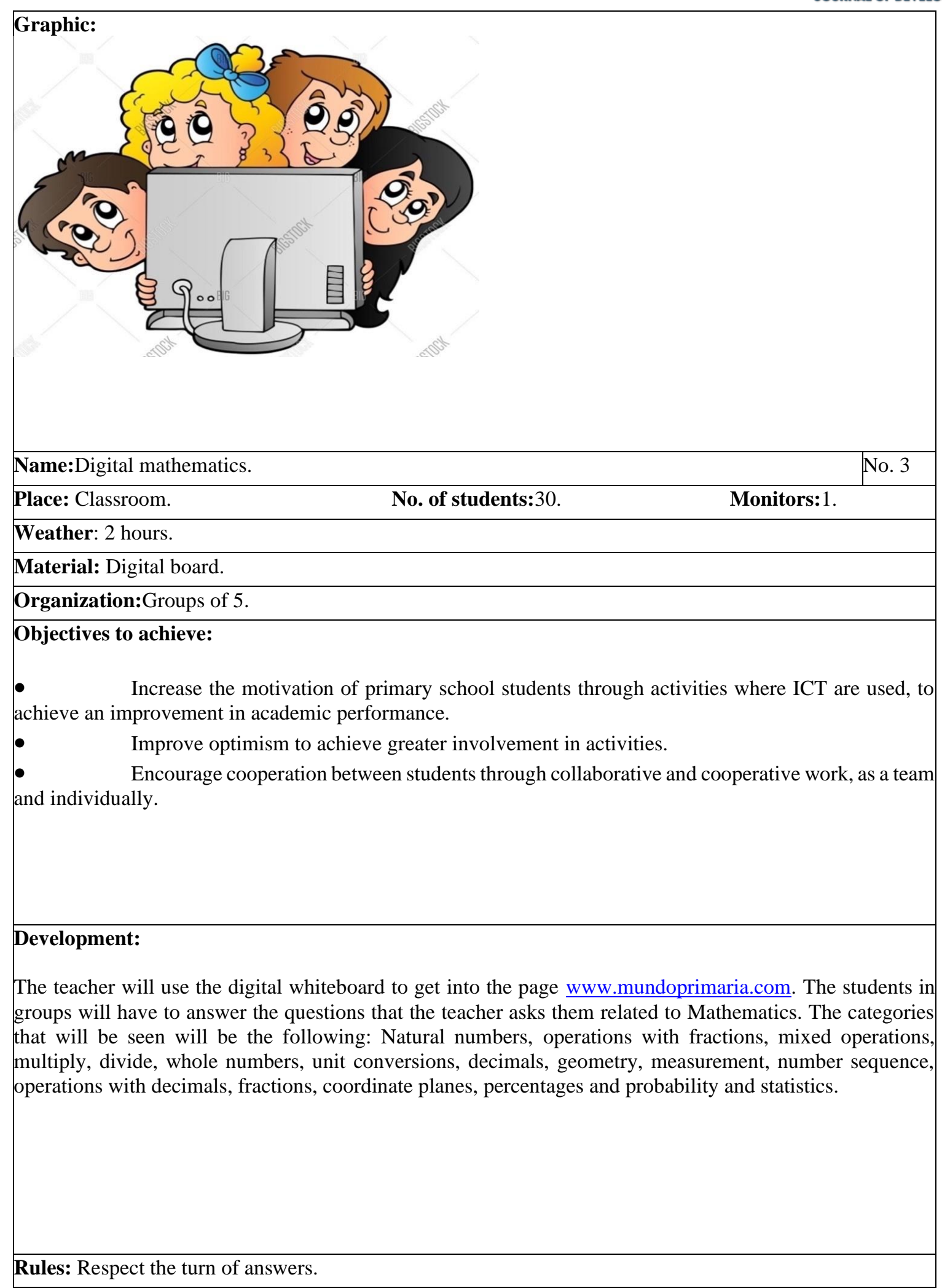




\section{Evaluation:}

- $\quad$ For each correct answer 5 points will be added to the group, and for each wrong answer nothing will be added. The questions will take turns. If a group misses an answer, the group that raises their hand first can answer it. The teacher will count the points on the board. At the end of the agreed number of questions, the counting will take place and the winning group will be decided.

\section{Graphic:}

\begin{tabular}{|l|l|}
\hline Name:Styles of music. & No. 4 \\
\hline Place: Classroom. & No. of students:30 \\
\hline Weather: 2 hours. & \\
\hline Material: Computers & \\
\hline Organization:Groups of $4-5$ people. & \\
\hline
\end{tabular}

\section{Objectives to achieve:}

- Increase the motivation of primary school students through activities where ICT are used, to achieve an improvement in academic performance.

- Make students aware of the importance of knowing how to handle new technologies.

- Improve optimism to achieve greater involvement in activities.

\section{Development:}

The students will form groups of 5. In the computer room they will have one computer each. The teacher will assign a different musical style to each group, for example, "Pop". They will have to answer the questions that the teacher demands, looking for information on the internet.

Rules: Be attentive to the teacher's explanations, and raise your hand if you want to ask questions about the activity. 


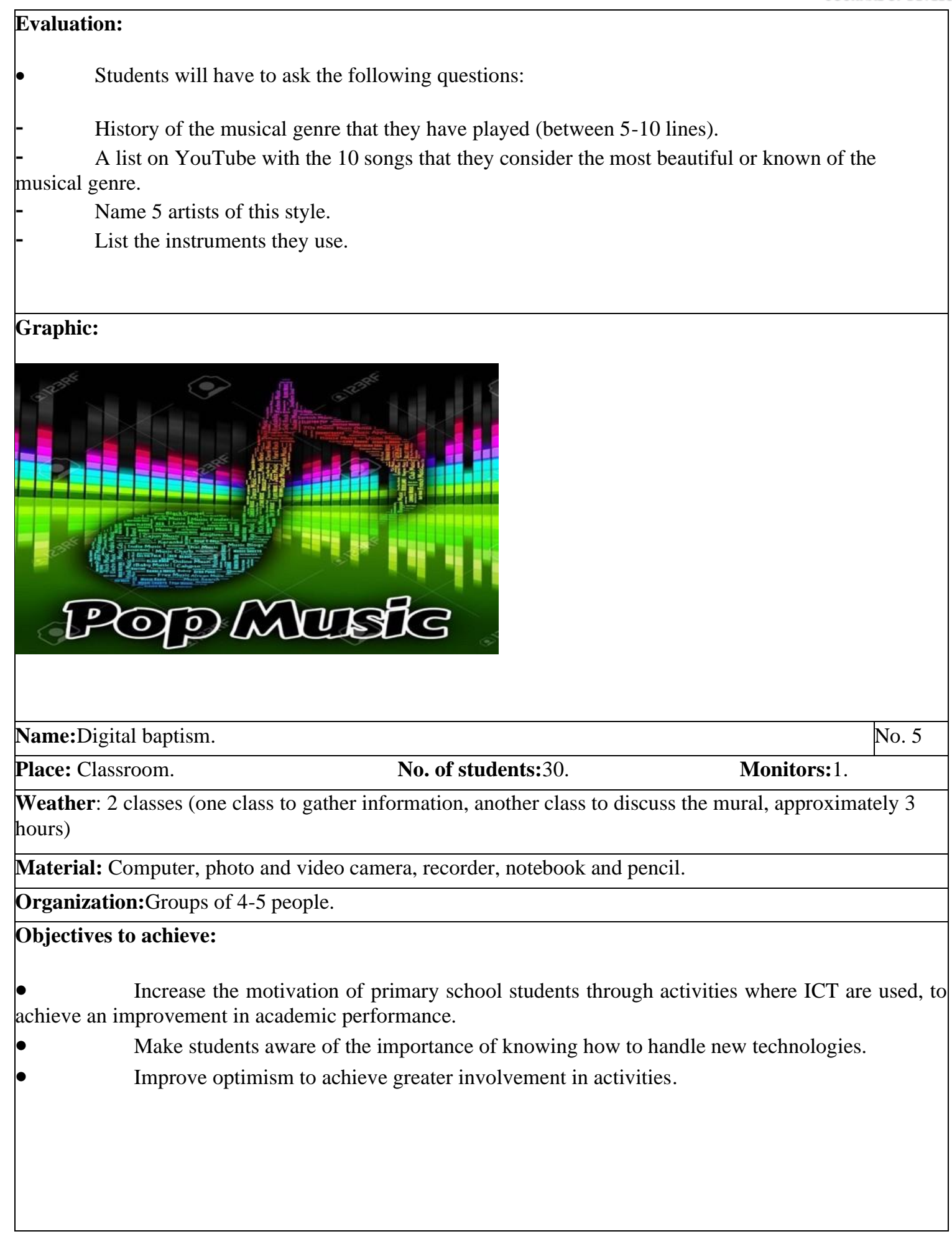


Development: An outing will be made to the parish chosen by the school. The priest will inform us of all the structural and material elements that make up the sacrament of Baptism. He will tell us what Baptism consists of and what it means for Christians. While all this is happening, photos, videos and recordings of the most important moments will be taken, so that later they will help in sharing with the class. The next day or on the date established by the teacher, the students will have to take a digital mural made, exposing all the information acquired by the corresponding electronic devices.

Rules: Be attentive to the teacher's explanations, and raise your hand if you want to ask questions about the activity.

\section{Evaluation:}

- The students through Glogster will make a digital mural exposing everything they have learned and will upload it to the center's social network. The groups will not only have to upload their digital mural, but they will also have to leave a comment on the network of the other class murals, providing their opinion.

\section{Graphic:}

\begin{tabular}{|l|l|}
\hline Name: In search of Europe. & No. 6 \\
\hline Place: Classroom. & No. of students:30. \\
\hline Weather: 2 hours. & Monitors: 1. \\
\hline Material: Computers \\
\hline Organization:individual. \\
Objectives to achieve: \\
Increase the motivation of primary school students through activities where ICT are used, to achieve \\
an improvement in academic performance. \\
Facilitate digital and audiovisual literacy to know and use ICT appropriately. \\
Improve optimism to achieve greater involvement in activities.
\end{tabular}




\section{Development:}

In the computer room, individual students will have to look for the capitals of the European countries mentioned by the teacher. They will rely on the Google Earth application to collect all the information. In the information cards you can find the most important reference points of each capital.

Rules: Be attentive to the teacher's explanations, and raise your hand if you want to ask questions about the activity.

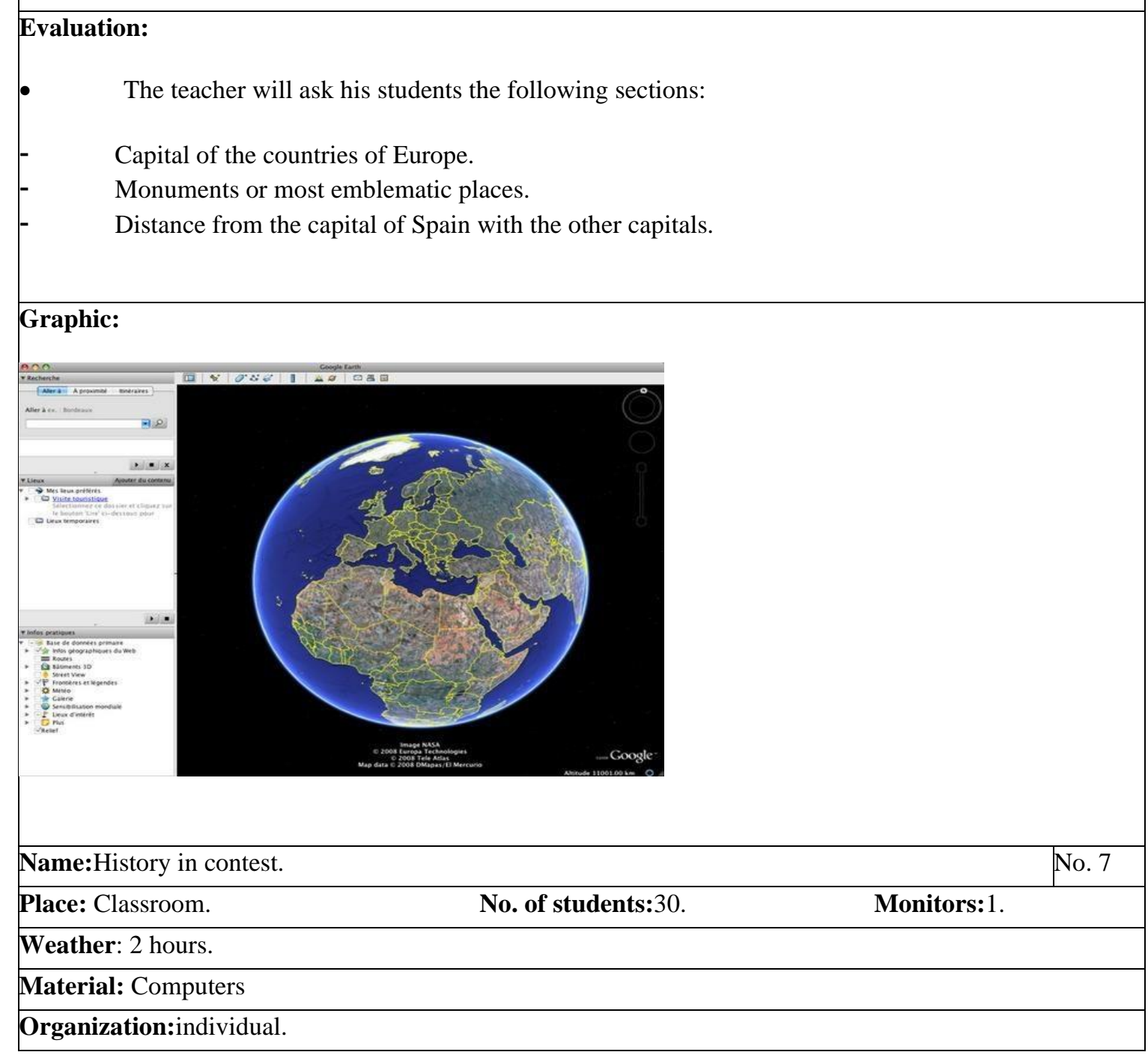




\section{Objectives to achieve:}

- Increase the motivation of primary school students through activities where ICT are used, to achieve an improvement in academic performance. in a playful way.

Increase the psychological aspects of primary school students, to achieve the learning objective The

- Improve optimism to achieve greater involvement in activities.

\section{Development:}

The students in the computer room will enter the application already downloaded from the "Time Machine". Once there, they will enter the third cycle and in the section "the time machine". They will find information that they will have to read and also auditions of historical times such as: Prehistory, History, Romanization, Feudalism, Reconquest, religions and the coexistence of cultures, the discovery of America: The trips of Columbus, key characters of the Modern Age in Spain, our life today and life at the beginning of the 19th century, Spain in Europe.

Rules: Be attentive to the teacher's explanations, and raise your hand if you want to ask questions about the activity.

\section{Evaluation:}

- Students will enter "the great game of the Time Machine." This game consists of asking questions related to the information previously seen, with 3 possible answers. Each correct answer will add 10 points, and each wrong answer will subtract 2 points. Finally, each student will publish the final score on the center's network.

\section{Graphic:}

\begin{tabular}{|l|l|}
\hline Name:Interactive social network. & No. 8 \\
\hline Place: At home and class. & No. of students: 30. \\
\hline Weather: 2 hours. & \\
\hline Material: Computers & \\
\hline Organization:individual. & \\
\hline
\end{tabular}






\subsection{MEANS}

For the preparation and development of this innovation project, several elements will be necessary.

Regarding the materials, the students will need a series of objects in order to carry out all the activities that we have below. 
The materials for a day must be those observed in Table 1 .

While the necessary applications will be seen in Table 2 .

Table 1. Material necessary to carry out the activities.

\begin{tabular}{|l|l|}
\hline $\begin{array}{l}\text { 1. Blackboard digital and material } \\
\text { complementary }\end{array}$ & \\
\hline $\begin{array}{l}\text { 2. Computers } \\
\text { complementary }\end{array}$ & \\
\hline 3. Photo camera & \\
\hline 4. Video camera & \\
\hline 5. Recorder \\
\hline 6. Pencil \\
\hline 7. Ballpoint pen \\
\hline 8. Notebook \\
\hline 9. Helmets \\
\hline 10. Classroom of 5th of Primary \\
\hline 11. Computer room \\
\hline
\end{tabular}

In addition to the materials necessary to carry out the activities, the teacher will need a series of applications to be able to develop the activities in the most optimal way possible. For this, the following tools will be used.

Table 2: Applications to perform the activities

\begin{tabular}{|l|}
\hline 1. Mundoprimaria.com \\
\hline 2. Glogster \\
\hline 3. Google Earth \\
\hline 4. Time machine \\
\hline 5. Twiducate \\
\hline
\end{tabular}

Regarding participation and motivation, the teacher will use a form for each student, in which he will fill in a series of parameters with which he can determine if the students have collaborated in the activities, have been active in them, etc. .

For this, a file is proposed where the teacher will take into account several aspects: participation in the activities proposed by the teacher, answering the questions raised, helping colleagues who need it, asking questions, punctuality, behavior and, finally, predisposition of each student to carry out activities (Annex 1).

These files will be filled out by the teacher in each of the activities carried out.

For each of the commented parameters, the teacher can indicate if they take place "Always", "Almost always", "Sometimes" or "Never". The student will be considered to have adequate participation and motivation in class if the seven variables have an "Almost always" or "Always". If in only one of them the student 
has obtained "Sometimes", or "Never", it will not be considered as adequate participation in the proposed activities.

A series of elements will also be needed with which the optimism of those students who carry out these activities will be evaluated. To do this, the following questionnaires will be used:

1. LOT-R Life-Revised Orientation Test, 1994 (Scheier, Carver \& Bridges, 1994): This is a selfreport that determines the general expectations towards positive or negative results about the future. It consists of 10 items. 3 of them with an optimistic direction, 3 in a negative direction, and the remaining 4 are fillers to hide the intention of the study (Ortín, Garcés de los Fayos, Joan Gosálvez, Ortega \& Olmedilla, 2011); all of them on a 5-point Likert scale (Annex 2).

Regarding the human resources that will be necessary for the development of this innovation project, the professors that will be needed to carry out the activities will be taken into account.

\section{EVALUATION}

This section of the TFG aims to obtain evidence of achievement of the objectives set.

This evaluation refers to the Project, not the students. For this, the following evaluation criteria and instruments will be used.

In the first place, the results obtained by the different Primary courses in the centers that are part of our study will be compared. As has been commented, the 4 centers must have the same characteristics: obtain 3 groups of 5th grade of Primary, and in which the previous year has not carried out a Didactic Unit similar to the one in this work.

In this way, the results of the students belonging to the 2018/2019 academic year, who will not have carried out activities related to ICT, and the students of the 2019/2020 year, who will carry out the proposed Didactic Unit, will be compared with activities where technology has An important paper.

Thus, the teacher will be able to assess the difference in grades from one year to another, influenced by the performance of these activities. In the same students, the results obtained each evaluation will also be compared, to observe the change over time.

The objective will be considered to have been met if the marks of the students who practice this didactic unit are better than the marks of the non-practitioners.

In relation to the specific objectives, as mentioned are five.

The following tables will show the evaluation criteria to assess the achievement of each of the proposed objectives (Table 1), and the instruments used to study it. (Table 2). 
Table 1. Evaluation criteria and relationship with specific objectives.

\begin{tabular}{|l|l|}
\hline EVALUATION CRITERIA & OBJECTIVES \\
\hline A) The student participates in the sessions carried out & 2 \\
\hline B) The student interacts with his classmates & 3 \\
\hline $\begin{array}{l}\text { C) The student helps his classmates in more stretches } \\
\text { complicated when necessary }\end{array}$ & 3 \\
\hline \begin{tabular}{l} 
D) The student improves his grades \\
\hline E) The student does not miss any scheduled session
\end{tabular} \\
\hline $\begin{array}{l}\text { F) The student answers the questionnaires delivered by the } \\
\text { teacher to assess their optimism and psychological well-being in a satisfactory way }\end{array}$ & 4 \\
\hline
\end{tabular}

Table 2. Evaluation instruments and relationship with evaluation criteria.

\begin{tabular}{|l|l|}
\hline EVALUATION INSTRUMENTS & CRITERIA \\
\hline I. Participation in class & A, E \\
\hline II. Individual work & A, D, F \\
\hline III. Team work & B, C \\
\hline
\end{tabular}

Focusing on each of the objectives mentioned, it is important to comment on how they could be taken into account in the course of using it.

Regarding the specific objective No. 1, which refers to the students increasing their psychological well-being, the teacher will be able to know the values thanks to some surveys given to the students (Annex 2). Compliance with them by each of the students will be the way to achieve these results. Thanks to these surveys the teacher will know

if the completion of the Didactic Unit has benefited positively in these commented variables.

Regarding the specific objective $\mathrm{n}^{\circ} 2$, which talks about making students aware of the importance of handling new technologies, the teacher will be able to assess the achievement of this taking into account several aspects.

In the first place, seeing that the students do not miss any activity of the Didactic Unit, secondly, observing that they are able to function in the management of technologies in the 8 activities proposed, and, thirdly, the students will know the necessary information about the practice of said activities.

Regarding attendance at the sessions, the teacher will have a file for each student in which he will record the attendance / non-attendance at the different activities of the students in each group. (Annex 3)

On the other hand, in the last evaluation of each academic year, the teacher will have planned to carry out a simple exam with the basic aspects necessary for learning how to use new technologies, where they can verify that students have understood the importance of this use, its basic aspects and the correct way to use them. For this exam, no type of theoretical study material will be necessary, simply with the student's attendance at the sessions they will have understood what they need to know. This is because the objective of carrying out these activities is not based on evaluating the performance of these within the teaching content block, but simply a way to improve the academic performance of students. 
In specific objectives 3, 4, and 5, it is about improving involvement in activities and therefore academic success through group work during the established activities. For this, the teacher will be able to make use, first of all, of the academic qualifications of the students, both those of the year in which they are and of previous years to assess the difference. It will also take into account the level of participation mentioned above, valued by the aforementioned file (Annex 1).

\section{REFLECTION AND FINAL ASSESSMENT}

This innovative project is a method of improvement in teaching.

The present work has many options to be able to carry out. The main reason for this statement is the ease of having technological material in schools today.

In this sense, it is not difficult to work with students, using techniques that carry out the management of new technologies, always with the supervision of teachers. In addition, the students with whom we are dealing are responsible and aware enough to understand the need for order and precaution with these educational tools.

In addition to easy access to ICT, another aspect that guarantees the implementation of this project is the motivation that students have to carry out activities and work with attractive tools that are different from the more traditional ones.

In this way, having a moment to carry out a playful educational session, which pursues educational objectives, supposes a high participation of adolescents in the task.

Therefore, to make this project viable, it is only necessary to have a teacher (assuming a total of 25-30 students per class), technological material, and the correct training of the teacher in charge of teaching the activities.

Regarding the limitations that we can find with this project, the most important is the specific situation that certain students may present at some point. For example, a physical problem could be cited here, such as decreased visual acuity, problems in the psychomotor system that may involve some complication in the handling of technologies, etc.

On the other hand, I consider it necessary to mention the importance of an adequate use of these, since, if they are not used in moderation, they can lead to addiction, visual fatigue, isolation from the social environment, back pain, fatigue, etc. For this reason it is necessary to influence students in the importance of a responsible use of new technologies.

Regarding the usefulness of the project, the use of this activity has aimed to improve the academic performance of children belonging to the different courses of Primary Education in any subject.

The innovation obtained from this project is, basically, the use of fun and attractive activities in 
class to motivate students in class. Today's teachers must work hard and think of different ways to get their students to study, not get bored in class, and learn in the best possible way.

As a result of the experience in educational centers, it has been observed that, when a teacher says that an activity is planned through the use of technology, all the students are happy and are eager to do it.

For this reason, I consider the idea of this project interesting for its implementation. It is an idea that can greatly benefit the students, who will accept it with pleasure and in which a high participation is expected.

In the event that my project could be put into practice, it would obviously be necessary to study the situation of the students on whom the study would be carried out. It is important to keep in mind each of its characteristics, both psychological, physical and social.

Furthermore, the study of this theory could lead to the analysis of other motivational methods in the classroom. As far as technologies are concerned, we could focus on creating a subject oriented, basically, on the use of these, since we live in a society in which new technologies are an inherent part of our world, which are evolving every day.

On the other hand, I consider the use of this research to improve other aspects of students' lives of great importance. As already mentioned in previous paragraphs, part of the objective of this work is to show that carrying out activities related to technology brings with it an increase in motivation, so that the academic performance of students could be improved.

We are referring to a way to improve the psychological characteristics of students. That is, if it is possible to demonstrate that activities through the use of ICTs favor children, that they are happier and have greater motivation, we can not only use it in education, but in other facets of life such as the relationship with the rest of the people, the self-acceptance, the achievement of objectives that are raised not related to the studies, in short, their happiness in general.

The work and time that I have dedicated to this TFG have helped me, in my opinion, my future as a teacher. I believe that thinking of a way to improve the work done by teachers is a very effective method of realizing, in part, how difficult it is to teach students correctly.

That is why teachers must work hard on new teaching methods, alternatives in education and different from traditional methods, so that students are motivated and thus improve their academic performance, managing to do this in a fun way. 


\section{BIBLIOGRAFÍA}

1. Borja, Y.A. y Gutiérrez, G.F. (2016). Las TICS en la Educación. Una perspectiva de las investigaciones al respecto. Publicando, 3(8), 59-69.

2. Buxarrais, M.R. (2016). Redes sociales y educación. Education in the knowledge society, 17(2), 1520 .

3. Cabero, J., Barroso, J., Llorente, M.C. y Yanes, C. (2016). Redes sociales y Tecnologías de la Información y la Comunicación en Educación: aprendizaje colaborativo, diferencias de genero, edad y preferencias. Revista de Educación a Distancia, (51).

4. Cladellas, R. y Castelló, A (2010). Aportaciones y perjuicios de las TIC's a la educación. Barcelona: Universitat Autònoma de Barcelona.

5. De Haro, J.J. (2010). Redes Sociales en Educación. En C. Naval, S. Lara, C. Ugarte y Ch. Sádaba (eds), Educar para la comunicación y la cooperación social (pp. 203-215). Pamplona: Consejo Audiovisual de Navarra.

6. Fuentes, L.R., Carrera, A.A. y Fernández, J.E. (2017). El rol de las Tics en el desempeño del Docente. Dominio de las Ciencias, 3(3), 274-290.

7. García-Valcárcel, A. y Basilotta, V. (2015). Evaluación de una experiencia de aprendizaje colaborativo con TIC desarrollada en un centro de educación primaria. Revista Electrónica de Tecnología Educativa, (51).

8. Guitert, M. y Pérez-Mateo, M. (2013). La colaboración en la red: hacia una definición de aprendizaje colaborativo en entornos virtuales. Teoría de la Educación. Educación y Cultura en la Sociedad de la Información, 14(1), 10-31.

9. Hernández, R.M. (2017). Impacto de las TIC en la educación. Propósitos y representaciones, 5(1), 325-347.

10. Jorrín, I.M., Vega, G. y Gómez, E. (2004). El papel facilitador de las TIC en un proceso de aprendizaje colaborativo. Revista Latinoamericana de Tecnología Educativa, 3(1).

11. Muñoz, M.M., Fragueiro, M.S. y Ayuso, M.J. (2013). La importancia de las redes sociales en el ámbito educativo. Escuela abierta: revista de Investigación Educativa, 16, 91-104.

12. Ortín, F.J., Garcés de los Fayos, E.J., Joan Gosálvez, J., Ortega, E. y Olmedilla, A. (2011). Optimismo y ejecución en el deporte en situaciones adversas. Replicando a Seligman 1990. Revista de Psicología del Deporte, 20(2), 491-501.

13. Pérez, A. (2018). Uso de smartphones y redes sociales en alumnos/as de Educación Primaria. Prisma Social: revista de investigación social, (20), 76-91.

14. Pérez, M.S., Ortiz, M.G. y Flores, M.M. (2015). Redes sociales en Educación y propuestas metodológicas para su estudio. Ciencia, Docencia y Tecnología, 26(50), 188-206. 
15. Salinas, J. (2004). Innovación docente y uso de las TIC en la enseñanza universitaria. Revista Universidad y Sociedad del Conocimiento, 1(1).

16. Scheier, M. F., Carver, C. S. y Bridges, M. W. (1994). Distinguishing optimism from neuroticism (and trait anxiety, self-mastery, and self- esteem): A re- evaluation of the Life Orientation Test. Journal of Personality and Social Psychology, 67, 1063-1078.

17. Suasnabas, L.S., Ávila, W.F., Díaz, E.J. y Rodríguez, V.M. (2017). Las Tics en los procesos de enseñanza y aprendizaje en la educación universitaria. Dominio de las Ciencias, 3(2), 721-749.

18. Zañartu, L.M. (2011). Aprendizaje colaborativo: una nueva forma de Diálogo Interpersonal y en red. Revista digital de educación y nuevas tecnologías. Contexto educativo, 28. 